\title{
Correction to: Activation of the phagocyte NADPH oxidase/NOX2 and myeloperoxidase in the mouse brain during pilocarpine-induced temporal lobe epilepsy and inhibition by ketamine
}

\author{
Fatma Tannich ${ }^{1,2,3} \cdot$ Asma Tlili $^{3,5} \cdot$ Coralie Pintard $^{3} \cdot$ Amina Chniguir $^{3,6} \cdot$ Bruno Eto $^{4} \cdot$ Pham My-Chan Dang ${ }^{3}$. \\ Ouajdi Souilem $^{1} \cdot$ Jamel El-Benna ${ }^{3}$ (1)
}

Published online: 4 January 2021

(c) Springer Nature Switzerland AG 2021

\section{Correction to: Inflammopharmacology (2020) 28(2):487-497 https://doi.org/10.1007/s10787-019-00655-9}

We regret that in the original article, the same $\mathrm{p} 47^{\text {phox }}$ western blot was used in Figure 2(a) and Figure 3(a). Actually, the same mice brain extracts were used in both figures, and we thought it was more accurate to check whether in the same mice brain extracts used in Figure 2a, p4 $7^{\text {phox }}$ was also phosphorylated as shown in Figure 3a. In the corrected version of Fig. 3, we have now used new mice brain extracts to provide new western blots of $\mathrm{p} 47^{\text {phox }}$, phospho-Ser315, phosphor-Ser328 and new statistics. We apologize for any convenience caused by this duplication.

The original article can be found online at https://doi.org/10.1007/ s10787-019-00655-9.

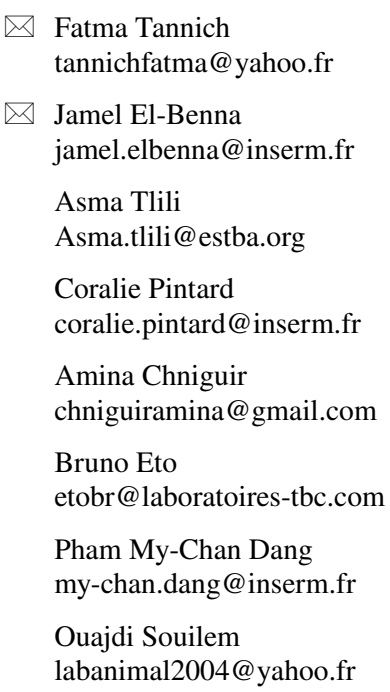

1 Laboratory of Physiology and Pharmacology, National School of Veterinary Medicine, University of Manouba, Sidi Thabet, Tunisia

2 Neurophysiology Laboratory and Functional Pathology, Department of Biological Sciences, Faculty of Sciences of Tunis, University Campus of Al-Manar, Tunis, Tunisia

3 INSERM U1149, ERL 8252 CNRS, Centre de Recherche sur l'Inflammation, Université Paris Diderot, Sorbonne Paris Cité, Laboratoire d'Excellence Inflamex, Faculté de Médecine, Site Xavier Bichat, 16 rue Henri Huchard, Paris 75018, France

4 Laboratoires TBC, Faculty of Pharmaceutical and Biological Sciences, 59006 Lille, France

5 Present Address: Ecole Supérieure des Techniques de Biologie (ESTBA), 56 rue Planchat, Paris 75020, France

6 Present Address: Faculty des Sciences de Gabes, University of Gabes, Gabes, Tunisia 
(a)

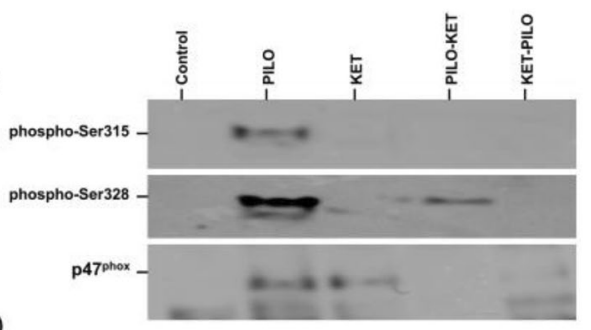

(b)

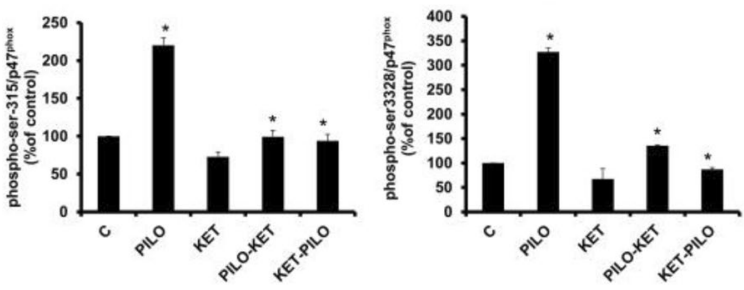

Fig. 3 Effects of pilocarpine and ketamine administration on the phosphorylation of $\mathrm{p} 47^{\mathrm{phox}}$ in mice brain. Mice were injected with pilocarpine alone or with ketamine, killed, and the brains homogenized as described in the methods section. The proteins were denatured by adding $5 \mathrm{X}$ concentrated modified Laemmli sample buffer. After denaturation, the tissue homogenates of brain (eq. of $25 \mu \mathrm{l} /$ well) were subjected to SDS-PAGE (10\%) and analyzed by western blotting using specific rabbit anti-phospho-Ser315-p47 $7^{\text {phox }}$ and anti-phosphoSer328-p47 ${ }^{\text {phox }}$ polyclonal antibodies. The blots were reprobed with rabbit anti-p47 $7^{\text {hox }}$ antibody as loading control (Fig. 3a). The ratio of phospho-p4 $7^{\text {phox }}$ to the total amount of $\mathrm{p} 47^{\text {phox }}$ was quantified using ImageJ $1.43 \mathrm{u}$ software. Values are expressed as mean $\pm \mathrm{SEM}$ of six independent experiments. With $\mathrm{p}<0.05$ were considered significant (*) indicated significance for ketamine or pilocarpine vs. control and PILO-KET and KET-PILO vs. PILO 